\title{
SERUM ALKALINE PHOSPHATASE IN HETEROTOPIC PARA-ARTICULAR OSSIFICATION AFTER TOTAL HIP REPLACEMENT
}

\author{
RAYMOND A. B. MOLLAN \\ From the Withers Orthopaedic Centre, Musgrave Park Hospital, Belfast
}

\begin{abstract}
Estimations of serum alkaline phosphatase were carried out prospectively on a series of patients having a total hip replacement. The levels of serum alkaline phosphatase before operation indicated a group of patients who subsequently developed heterotopic ossification. Levels of this enzyme after operation did not indicate those patients who were developing heterotopic ossification.
\end{abstract}

Para-articular heterotopic bone formation is often seen on radiographs after a total hip replacement. Only a small number of patients, however, develop sufficient new bone seriously to limit the range of movement of their arthroplasty but such patients have a very poor clinical result. When ossification has developed around one implant there is a 92 per cent chance of it developing around the other if bilateral arthroplasties are carried out (DeLee, Ferrari and Charnley 1976). The incidence of heterotopic ossification is surprisingly high in published series and significant degrees, causing serious clinical impairment, are reported to occur as commonly as other major complications of hip replacement (Table I). Despite the reported frequency of this complication little work has been published on how patients with this predisposition might be identified. If it were possible to

Table I. Reported incidence of heterotopic ossification after total hip replacement

\begin{tabular}{|l|c|c|c|}
\hline \multicolumn{1}{|c|}{ Authors } & $\begin{array}{c}\text { Number of } \\
\text { patients }\end{array}$ & $\begin{array}{c}\text { Percentage } \\
\text { with } \\
\text { ossification }\end{array}$ & $\begin{array}{c}\text { Percentage with } \\
\text { clinically serious } \\
\text { ossification }\end{array}$ \\
\hline $\begin{array}{l}\text { Hamblen, Harris } \\
\text { and Rottger (1971) } \\
\begin{array}{l}\text { Brooker } \text { et al. } \\
(1973)\end{array}\end{array}$ & 422 & 20.0 & 3.0 \\
$\begin{array}{l}\text { Lazansky (1973) } \\
\begin{array}{l}\text { Nollen and Slooff } \\
\text { (1973) }\end{array}\end{array}$ & 501 & 21.0 & 2.0 \\
$\begin{array}{l}\text { Matos, Amstutz } \\
\text { and Finerman } \\
\text { (1975) } \\
\begin{array}{l}\text { DeLee } \text { et al. } \\
\text { (1976) }\end{array}\end{array}$ & 221 & 51.0 & 0.5 \\
$\begin{array}{l}\text { Beckenbaugh and } \\
\text { llstrup (1978) }\end{array}$ & 333 & 14.6 & 7.0 \\
\hline
\end{tabular}

identify these patients, either before or after operation, then prophylactic treatment to limit the amount of bone induced might be a practical outcome.

Nollen and Slooff (1973) reported that in severe para-articular ossification there was a rise in the serum alkaline phosphatase three weeks after operation. This enzyme had long been associated with calcification. In neurological diseases, paraplegia and head injury, where new bone formation can be of startling dimensions, the serum alkaline phosphatase has been found to be markedly elevated while new bone was being formed (Furman, Nicholas and Jivoff 1970). As systemic factors appeared to play a dominant role (DeLee et al. 1976) the serum alkaline phosphatase was considered worthy of investigation as an indicator of those patients who were predisposed to heterotopic ossification and also as an indicator of those patients already forming new bone of clinically significant proportions.

\section{MATERIAL AND METHOD}

In 1976,250 consecutive patients admitted to this hospital for total hip replacement were considered for this prospective trial. A proforma was completed on admission and this form accompanied the patient at each stage of treatment to the final outpatient follow-up two years later. A history was recorded to exclude any patient who had had a previous operation on the hip, any with known metabolic, gastro-intestinal and genitourinary disease, and any with dietary aberrations or on drugs which might alter bone metabolism; blood tests were carried out to exclude those with renal and hepatic impairment. A total of 131 patients were suitable for further study.

All patients had the levels of serum alkaline phosphatase, calcium and phosphorus estimated before operation, ten days after operation, and at the 
Table II. Classification of heterotopic ossification (Brooker $e t$ al. 1973)

\begin{tabular}{|l|l|}
\hline Class I & $\begin{array}{l}\text { Islands of bone in soft tissue } \\
\text { Bony spurs with more than one centimetre } \\
\text { between opposing surfaces }\end{array}$ \\
Class III & $\begin{array}{l}\text { Bony spurs with less than one centimetre } \\
\text { between opposing surfaces }\end{array}$ \\
Class IV & Apparent bony ankylosis of joint \\
\hline
\end{tabular}

two-month and four-month outpatient follow-up appointments; the serum alkaline phosphatase was estimated using the kit prepared by General Diagnostics, which used phenolphthalein monophosphate as the substrate, the usual range for our group of laboratories being 21 to 91 international units per litre ( 3 to 13 King-Armstrong units per litre). The operations were performed by a number of surgeons using different techniques; the majority, however, were Charnley and Howse low-friction arthroplasties carried out without trochanteric osteotomy. Operative details and blood loss were recorded. Serial radiographs were taken and were examined separately two years after arthroplasty and the amount of heterotopic ossification was classified according to the method of Brooker et al. (1973), which is summarised in Table II; these results were then recorded on the proformas.

\section{RESULTS}

All 131 patients had osteoarthritis. There were eightyfive women and forty-six men, with an average age of sixty-five years (range twenty-eight to eighty-one years). There were seventy-three Charnley and fiftyeight Howse low-friction arthroplasties and there was no correlation between type of arthroplasty and heterotopic ossification or level of serum alkaline phosphatase after operation. The sexes were equally affected by subsequent heterotopic ossification.

The serum alkaline phosphatase was elevated before operation in forty-five patients of whom fourteen had radiological evidence of heterotopic ossification. These are analysed further in Table III. One patient consistently had levels between 250 and 300 international units per litre but was clinically and radiologically normal and no pathological cause was found for the greatly elevated level. There were eighty-six patients who had normal levels before operation ten of whom produced new bone, six of these ten having a higher-than-normal alkaline phosphatase after operation. Thirty-eight of the patients who had a normal level before operation had a rise afterwards (though not all to abnormal levels), but thirty-two of them did not have any radiological sign of new bone (Table IV).

A statistical analysis of the relationship between serum alkaline phosphatase before operation and the risk of heterotopic ossification was made using Armitage's (1971) test for trends in proportions. This revealed a highly significant relationship $\left(\chi^{2}=7.23\right.$ with 1 d.f., $P<0.01)$ between increasing levels of alkaline phosphatase and increasing risk of heterotopic ossification. A similar analysis of the relationship between serum alkaline phosphatase after operation and the risk of heterotopic ossification found no evidence of any significant relationship ( $\chi^{2}=0.516$ with 1 d.f.).

There was a total of twenty-four patients who had radiological evidence of ossification, an incidence of 18.3 per cent. At two years none of these patients had

Table III. Levels of alkaline phosphatase before operation related to the subsequent development of heterotopic ossification

$\left.\begin{array}{|c|c|c|c|}\hline \begin{array}{c}\text { Alkaline phosphatase } \\ (\text { i.u. /litre) }\end{array} & \begin{array}{c}\text { Number of } \\ \text { patients }\end{array} & \begin{array}{c}\text { Number } \\ \text { developing } \\ \text { new bone }\end{array} & \begin{array}{c}\text { Percentage } \\ \text { developing } \\ \text { new bone }\end{array} \\ \hline 21-91 \text { (normal) } & 86 & 10 & 11.6 \\ 92-100 & 20 & 6 & 30.0 \\ 101-120 & 18 & 5 & 27.8 \\ >120 & 7 & 3 & 42.9\end{array}\right\}$

Table IV. Levels of alkaline phosphatase after operation related to the presence of heterotopic ossification

\begin{tabular}{|c|c|c|c|}
\hline $\begin{array}{c}\text { Alkaline phosphatase } \\
(\text { i.u./litre })\end{array}$ & $\begin{array}{c}\text { Number of } \\
\text { patients }\end{array}$ & $\begin{array}{c}\text { Number } \\
\text { developing } \\
\text { new bone }\end{array}$ & $\begin{array}{c}\text { Percentage } \\
\text { developing } \\
\text { new bone }\end{array}$ \\
\hline $21-91$ & 60 & 8 & 13.3 \\
$92-100$ & 20 & 6 & 30.0 \\
$101-120$ & 34 & 7 & 20.5 \\
$>120$ & 17 & 3 & 17.6 \\
\hline Overall & 131 & 24 & 18.3 \\
\hline
\end{tabular}

any symptoms or clinical signs of heterotopic bone formation nor any restriction in range of movement. There was no correlation between the degree of ossification, classified according to Brooker, and the level of alkaline phosphatase. The heterotopic ossification produced a steady increase in bone formation for two to four months after operation. The amount of new bone then became static and changed little over the subsequent twenty months.

\section{DISCUSSION}

The mechanism of heterotopic ossification and bone induction is not understood. A study of experimental systems indicates that the process is one of cell differentiation. Many and varied inductors of ossification are involved and it is uncertain which cell type is susceptible to induction. A physiological environment is vital and the process appears to be linked to normal 
homeostatic maintenance of the skeleton (Ostrowski and Wlodarski 1971). Three prerequisites have been suggested for the induction of bone in soft tissues: an inducing agent, a competent cell and an environment suitable for osteogenesis (Chalmers, Gray and Rush 1975). The formation of bone by non-specialised cells in extraskeletal sites has been proven (McKibbin 1978) and in every total hip replacement competent cells abound in residual debris and repair tissue. The problem has been to identify which patient has either the suitable local inducer or the systemic factor enabling soft-tissue osteogenesis. This study would suggest that although patients with elevated alkaline phosphatase levels before operation are at almost three times the risk of developing heterotopic ossification compared with patients with normal levels it must be remembered that, even in this high-risk group, two out of three patients did not develop heterotopic ossification. Such an "at risk" indicator, although clearly superior to chance, must be considered to be of limited practical reliability. High levels may be normal for individual patients. These have been observed previously in a different context
(McCorry, Mollan and Neely 1974) and may represent an inborn error in metabolism.

The levels after operation showed no correlation with production of new bone. It is known that serum alkaline phosphatase increases after any skeletal trauma (Nilsson and Westlin 1972) and this study reflects the observation that the timing of the rise and its magnitude varies with the degree of skeletal disturbance (Hosking 1978). Thus, when interference with the bone skeleton has occurred, the elevation of serum alkaline phosphatase levels observed by Nollen and Slooff (1973) could be due to skeletal trauma rather than to heterotopic ossification.

This study did show, however, that in this centre although 18.3 per cent of patients had radiological evidence of heterotopic bone formation, no patient developed symptoms or clinical signs of loss of function as a result. In a subsequent study in this centre serious clinical impairment of the arthroplasty as a result of heterotopic ossification was found to be rare and it is not considered to be a major complication of total hip replacement.

I would like to thank the surgeons, the secretarial and laboratory staff of the Withers Orthopaedic Unit without whose help this study would have been impossible, and Professor R. I. Wilson for instigating this study and for his help and encouragement. I would also thank Dr T H. Hassard of the Department of Medical Statistics, Queen's University, Belfast, for his invaluable help in the statistical analysis.

\section{REFERENCES}

Armitage, P. (1971) Statistical Methods in Medical Research, pp. 363-365 Oxford: Blackwell Scientific Publications.

Beckenbaugh, R. D., and Ilstrup, D. M. (1978) Total hip arthroplasty. Journal of Bone and Joint Surgery, 60-A, 306-313.

Brooker, A. F., Bowerman, J. W., Robinson, R. A., and Riley, L. H., Jun. (1973) Ectopic ossification following total hip replacement. Journal of Bone and Joint Surgery, 55-A, 1629-1632.

Chalmers, J., Gray, D. H., and Rush, J. (1975) Observations on the induction of bone in soft tissues. Journal of Bone and Joint Surgery. 57-B, 36-45.

DeLee, J., Ferrari, A., and Charnley, J. (1976) Ectopic bone formation following low friction arthroplasty of the hip. (linical Orthopaedics and Related Research, 121, 53-59.

Furman, R., Nicholas, J. J., and Jivof, L. (1970) Elevation of the serum alkaline phosphatase coincident with ectopic-bone formation in paraplegic patients. Journal of Bone and Joint Surgery, 52-A, 1131-1137.

Hamblen, D. L., Harris, W. H., and Rottger, J. (1971) Myositis ossificans as a complication of hip arthroplasty. Journal of Bone and Joint Surgery, 53-B, 764.

Hosking, D. J. (1978) Changes in serum alkaline phosphatase after femoral fractures. Journal of Bone and Joint Surgery, 60-B, 61-65.

Lazansky, M. G. (1973) Complications revisited: the debit side of total hip replacement. Clinical Orthopaedics and Related Research, 95, $96-103$.

Matos, M., Amstutz, H. C., and Finerman, G. (1975) Myositis ossificans following total hip replacement. Journal of Bone and Joint Surgery, 57-A, 137

McCorry, R. L., Mollan, R. A. B., and Neely, M. R. (1974) A clinical trial of the values of serum heat stable alkaline phosphatase estimates in predicting the occurrence of pre-eclampsia. Journal of Obstetrics and Gynaecology of the British Commonwealth, 81, 701-705.

McKibbin, B. (1978) The biology of fracture healing in long bones. Journal of Bone and Joint Surgery, 60-B, $150-162$.

Nilsson, B. E., and Westlin, N. E. (1972) The plasma concentration of alkaline phosphatase, phosphorus and calcium following femoral neck fracture. Acta Orthopaedica Scandinavica. 43, 504-510.

Nollen, A. J. G., and Sloof, T. J. J. H. (1973) Para-articular ossifications after total hip replacement. Acta Orthopaedica Scandinavica, $44,230-24 i$

Ostrowski, K., and Wlodarski, K. (1971) Induction of heterotopic bone formation. In The Biochemistry and Physiology of Bone. Second Edition. Volume III. Chapter 9, pp 299-336. Edited by G. H. Bourne. New York and London: Academic Press. 